Journal of Social Sciences 1 (4): 238-239, 2005

ISSN 1549-3652

(C) 2005 Science Publications

\title{
Chemistry Education and Mythology
}

\author{
Sule Aycan \\ Mugla University Faculty of Education, Mugla-Turkey
}

\begin{abstract}
This study aimed to investigate the effect of mythological story in teaching chemistry. To this end the students in the class were divided into two homogenous groups. While the first group was thought in a traditional way, using a mythological story thought the second group. The story used was based on a Mountain just opposite the faculty.
\end{abstract}

Key words: Mythology, chemistry education, niobium, tantalum

\section{INTRODUCTION}

Students sometimes perceive general chemistry to be list of obtuse principles to memorize and which hold no importance outside the classroom. Too infrequently does this class offer students a clear picture of what real chemists do, what the science of chemistry is, or how it is related to everyday life $\mathrm{f}^{[1]}$.

In chemistry courses at universities, education has mainly been centered on the lecturer's comprehension of a topic rather than that of the student. Recently, student-centered learning has aroused considerable interest in all levels of education systems, including universities. Several alternative methods, based on students being at the centre of control, have been suggested since Aristotle's time ${ }^{[2]}$. The science education literature contains several studies of student's understanding of scientific phenomena ${ }^{[3-12]}$. Teaching some uncommon elements at introductory level has made them obvious to the teachers. In this study, a mythological approach has been compared with with conventional teaching approach while teaching uncommon elements (niobium and tantalum).

\section{MATERIALS AND METHODS}

The participants of this study were 50-second year undergraduate chemistry students of Celal Bayar University in Manisa (Turkey). The study was conducted at 2004-2005 academic year. The students were divided into two homogeneous groups. After that, the features of niobium and tantalum elements were taught to the first group in a traditional way. Niobium $(\mathrm{Nb})$ and Tantalum $(\mathrm{Ta})$ are the same group elements in periodic Table. Some of their essentials are given in Table $1^{[13]}$.

Charles Hatchett, an English chemist in 1801, discovered niobium. He analyzed a specimen of an unknown mineral from the collection of the British Museum in London. This heavy black mineral was later called columbite. Anders Gustaf Ekeberg discovered and named tantalum in 1802. He embarked on a teaching career at Uppsala where he presented chemical expositions and analyzed minerals. One mineral he investigated became known as yttrotantalite from Ytterby, Sweden and the other was from Kimito, Finland.

In 1809, William Hyde Wollaston, a British chemist, analyzed both columbite and tantalite mineral specimens and claimed that columbium and tantalum were the same element ${ }^{[14,15]}$. A quiz was applied to the students at the end of the lesson. Only 5 students out of 25 students, at first group gave right answers. The success rate is $10 \%$. A mythological story was told to the second group. The story was concerning Sypylos Mountain in Manisa (west of Turkey). Manisa province which has been established on the northern skirts of the mountain known as Sypylos since the ancient periods, is in one of the residential locations that could continue its life until today ${ }^{[16]}$. Celal Bayar University Chemistry Department is located opposite this mountain.

Niobe is one of the more tragic figures in mythology. She was the daughter of Tantalus and had two brothers; Broteas and Pelops. Niobe was the queen of Thebes, married to Amphion, King of Thebes. Niobe and Amphion had fourteen children and in a moment of arrogance, Niobe bragged about her seven sons and seven daughters at a ceremony in honor of Leto, the daughter of the titans Coeus and Phoeb. She mocked at Leto, who only had two children, Apollo, god of prophecy and music and Artemis, virgin goddess of the wild. Leto did not take the insult lightly and in retaliation, sent Apollo and Artemis to earth, so slaughter all of Niobe's children. Apollo killed the seven sons while they practiced their athletics. The last son begged to be spared, but the arrow had already left Apollo's bow and the boy was struck dead. Artemis killed the seven daughters with her lethal arrows.

At the sight of his dead sons, Amphion either committed suicide or was also killed by Apollo to avenge his children's deaths. In any event, Niobe's entire family was dead in a matter of minutes. In shock, she cradled the youngest daughter in her arms and then fled to Mt. Sypylos in Asia Minor. 
Table 1: Some features of Niobium and Tantalum

\begin{tabular}{lll}
\hline & Nb & Ta \\
\hline Atomic number & 41 & 73 \\
Group number & 5 & 5 \\
Period number & 5 & 6 \\
Block & d-block & d-block \\
Standard state & solid at $298 \mathrm{~K}$ & solid at 298 K \\
Color & grey metallic & grey blue \\
Classification & metallic & metallic \\
Availability & foil, sheet, wire, insulated wire, powder, rod, turning and tube & foil, sheet, wire, insulated wire, powder, mesh and rod \\
\hline
\end{tabular}

There she turned to stone and from the rock forms a stream of her ceaseless tears. She became the symbol of eternal mourning. Niobe's children were left unburied for nine days because Zeus had turned all of the people of Thebes into stone. Only on the tenth day did the gods have pity and entomb her children.

Niobe is weeping even today. Carved on a rock cliff on Mt Sypylos is the fading image of a female. Composed of porous limestone, the stone appears to weep as the water after a rain seeps through it ${ }^{[17]}$. After this story, the same knowledge was given to the second group about $\mathrm{Nb}$ and $\mathrm{Ta}$, as told to the first group. Therefore, the students, in second group understood that Niobe is daughter of Tantalos. Niobium and tantalum have similar features, sot they are the same group like Niobe being the daughter of Tantalos. A quiz was applied to the students in the second group at the end of the lesson. 22 students out of 25 students at second group gave right answers. Their success rate is $88 \%$.

\section{RESULTS}

When the students learnt that the names of these two elements in the periodic table originated from the Mountain opposite their faculty, their interest in the subject increased and learning was facilitated. In this respect we can suggest that using this kind of mythological stories in the lesson would increase student's motivation and reinforce learning.

\section{REFERENCES}

1. Roy, A.H., R.R. Broudy, S.M. Auerbach and W.J. Vining, 1999. Teaching materials that matter: An interactive, multi-media module on zeolites in general chemistry. Chem. Educator, 4: 114-118.

2. Kurbanoglu, N.I., Y. Taskesenligil and M. Sozbilir, 2006. Programmed instruction revisited: A study on teaching Stereochemistry. Chem. Educ. Res. Prac., 7: 13-21.

3. Ozmen, H. and A. Ayas, 2003. Student's difficulties in understanding of matter in open and closed-system chemical reactions. Chem. Educ. Res. Prac., 4: 279-290.
4. Wajrak, M. and J. Rummey, 2004. Determination of silver by differential anodic stripping voltammetry: An APCEEL experiment. Aust. J. Ed. Chem., 63: 26-30.

5. Demircioglu, G., A. Ayas and H. Demircioglu, 2005. Conceptual change achieved through a new teaching program on acids and bases. Chem. Educ. Res. Prac., 6: 36-51.

6. Morgil, I., S. Yavuz, O. Oskay and S. Arda, 2005. Traditional and computer-assisted learning in teaching acids and base. Chem. Ed. Res. Prac., 6: 52-63.

7. Sarikaya, M., 2003. The application of an activity relating to the determination of Avogadro's number in a class of first-year science students. The Chem. Educator, 9: 1-4.

8. Calik, M., 2005. An analogy activity for incorporating student's conceptions of types of solutions. Asia-Pacific Forum on Science Learning and Teaching, 6: 1-3.

9. Kabbani, R.M., 1997. Conservation collaboration between art and science. The Chem. Educator, 2: 118.

10. Parraga, C., S.D. Brown and G. Richmond, 2004. A colorful catalysis. Wachanga, S.W. and J.G. Mwangi, 2004. Effect of the cooperative class experiment teaching method on secondary school student's chemistry achievement in Kenya's Nakuru district. Intl. Ed. J., 5: 26-36.

11. Cheesman, K., 2006. Using comics in the science classroom. J. College Sci. Teach., 35: 48-51.

12. Aycan, S., Anorganik Kimya II, (in Turkish).

13. Anooymous, Niobium (columbium), http://www.vanderkrogt.net/elements/elem/nb.html

14. Anonymous, http://www.webelements

15. Manisa 2000, Manisa Valiligi Yayını, Manisa, 2000 (in Turkish).

16. Anonymous, http://david-drake.com/ ovid/ niobe. html

17. Anonymous, drake.com/ovid/niobe.html http://david- 